\title{
Study of Inter-Relationship Between Perceived Workplace Discrimination, Job Stress, Mental Well-Being, And Job Performance of Teachers
}

\author{
Manoj Kumar Pandey ${ }^{1}$, Urmi Chakraborty ${ }^{2}$, Aditi Bapte ${ }^{3}$ \\ ${ }^{1}$ Assistant Professor, Department of Applied Psychology, Veer Bahadur Singh Purvanchal University, \\ Jaunpur. \\ ${ }^{2}$ Clinical Psychologist, Department of Clinical Psychology, Centre of Excellence in Mental Health, \\ ABVIMS \& Dr. RML Hospital, New Delhi \\ ${ }^{3}$ Research Assistant, Indian Council of Social Science Research, New Delhi. \\ Corresponding author: Urmi Chakraborty \\ Email: urmipsy83@gmail.com
}

\begin{abstract}
Background: This study was planned to investigate the consequences of perceived workplace discrimination on job stress, mental well-being, and teachers' job performance in higher education. A conceptual model was proposed to illustrate the relationship between the study variables.

Methodology: A correlational research design was adopted, and convenience sampling was used for data collection of 200 teachers. The participants of this study represented different streams of science and arts and were asked to fill questionnaires to collect relevant information on the subject matter.

Results: Results show that (a) workplace discrimination is significantly positively related to perceived job stress, negatively related to mental well-being and overall job performance. Further, stepwise regression analysis shows that perceived job stress, job tenure, and workplace discrimination explain significant contributions (job stress emerged as best predictors of job performance) to the job performance of teachers and while job stress and gender explain significant contributions (job stress again emerged as best predictors of mental well-being) to the mental well-being of teachers. Results have been discussed in light of previous studies.
\end{abstract}

Keywords: Workplace Discrimination, Perceived Job Stress, Mental Well-Being, Job Performance.

$$
\begin{aligned}
& \text { (Paper received }-28^{\text {th }} \text { August 2021, Peer review completed }-15^{\text {th }} \text { September 2021) } \\
& \text { (Accepted }-28^{\text {th }} \text { September 2021) }
\end{aligned}
$$

\section{INTRODUCTION}

The workplace is still a venue for discrimination

\section{Unknown}

Workplace discrimination is a persistent problem worldwide, despite legislation designed to prohibit and discourage these practices. According to the Equal Employment Opportunity Commission, 33,937 charges of race-based workplace discrimination, 24,582 age-based, 28,372 sex-based, and 10,601 charges related to national origin were filed in the 2008 fiscal year [1]. These U.S. estimates mark a record high informal complaint and a 15\% increase over those filed in 2007 [1].

However, these statistics likely underestimate such occurrences because minority group members often minimize these experiences [2] and are notably reluctant to file formal charges [3]. Workplace discrimination can range from the systematic denial of people's rights based on their gender, sexual orientation, religion, ethnicity, age or other criteria to more informal verbal abuse that orient such characteristics. In general, 
researchers found that members of gender, racial, or ethnic minority groups report workplace discrimination more often, and the consequences of this exposure are distinguishable from effects produced by other psychosocial features (e.g., decision-making control and performance expectations) of their occupations [46]. Discrimination is unequal treatment of individuals who have the similar worth based on age, race, caste, religion, gender, ethnicity, etc. Discrimination in any form of occupation means treating people differently in a way that undermines their position in any manner at their workplace. The characteristics range from race, colour, sex, religion, to political opinion, and social origin. In addition to the above listed reasons, employees and job applicants can also be discriminated against because of disabilities, genetic information, pregnancy, or because of their relationship with another person.

Comparison of races and gender in India reveal significant differences in earnings, unemployment rates, and allocation of certain occupations, and accumulation of human capital. There are various levels of discrimination in, society, such as access to education of individuals or groups, treatment of health ailments, the labour market, or how they are treated in educational organization. Although all types and levels of discrimination are equally concerning and related to each other, discrimination practices in higher education, especially with teachers of university and colleges in this research has been discussed.

The present study is designed to study consequences of perceived workplace discrimination on job stress, mental well-being, and teachers' performance in higher education.

\section{Direct and indirect discrimination}

Direct discrimination is when an individual treats, someone unfavourably because of a personal characteristic trait protected by law. The two types of discrimination being direct and indirect. Where, direct discrimination happens when it is seen that people make unfair assumptions about other person's personal characteristics. Like refusing to employee an individual because of age, gender etc., thinking that he/she is unfit for employability.

On the other hand, the second type of discrimination, indirect discrimination follows when an unreasonable condition is levied that hinders a person with a characteristic to a person protected by law. Indirect discrimination on the other hand happens when any workplace policy, or behaviour seems to treat all workers in the similar fashion, but it actually unfairly detriments an individual because of a characteristic protected by law. Such as a necessity for employees to work 12-hour shifts may appear to treat everyone equally. However, it may disadvantage employees who are caregivers in the family.

Internationally, the Equal Opportunity Act [7] sets out different personal characteristics that make discrimination in employment against the law. Federal anti-discrimination laws also apply to Victorian employers, and employees are protected from discrimination at all stages of employment, includes:

- The recruitment, as in how positions are advertised or as simple as how interviews are conducted for a job

- When being presented partial terms and conditions of employment

- When being denied benefits like, training opportunities, promotion, etc

- When being unethically dismissed, or demoted.

\section{Workplace discrimination in higher education}

Higher Education Research Institute at the University of California, Los Angeles in a major survey [8] highlights that professors worry about discrimination but they are not really prepared with classroom conflicts over diversity. The discrimination ranges from mentoring, pay and to politics. Discrimination is the very epicentre of stress for many faculty members, especially women and ethnic minorities.

Key purpose of this exploration was to gain prevalence data on teachers perceived experienced of discrimination at their workplace. The study is further based on 'perceived or actual sexual orientation, gender identity or intersex status' of the teachers. While it is encouraging that the majority of participants of the study did not report personally facing this form of workplace discrimination, 43 per cent percent of participants did- with 47 per cent of participants totally 'out' within their school community and report discrimination. 


\section{Workplace discrimination and job stress}

Several studies have explicitly named race-based discrimination as a general stressor [9-10] and an occupational stressor for black individuals [11]. Research had [12] found that $99.4 \%$ of the subjects in their study found racial discrimination to be stressful. Discrimination has been well-documented as a stressor for black Americans, and the stress associated with it has been associated to negative physical as well as psychological outcomes [13].

\section{Workplace discrimination and mental well-being}

Discrimination, leads to negative effects on its victims' well-being and health. Workplace discrimination is considered to be a stressor [14-15], such that those exposed to it may suffer a variety of negative consequences. Applying the classic psychological stressor-strain theory [16], detriments to victims' wellbeing may arise as a result of appraisals about the nature and source of the discrimination, which cause emotional and physiological arousal and, in turn, psychological strain symptoms. Negative impacts on attitudes (e.g., job satisfaction) may also be expected [15].

Research has provided evidence of these negative consequences of discrimination on well-being and job satisfaction, as well as the effects of other forms of aggression for victims [14-15] and we would expect discrimination to have negative effects on well-being and job satisfaction.

\section{Workplace discrimination and job performance}

The workplace discrimination usually represents grounds of discrimination in the form where the individuals often sense that mistreatment from their peers feel which results in negative work-related behaviours. Perceived discrimination is also associated with more extreme work withdrawal behaviours, it is largely identified that discrimination turns the employees emotionally brittle, simple peace-loving employees can change into paranoid, suspicious, fearful and angry individuals. Elimination of gender discrimination is critical for the satisfaction and motivation, commitment and enthusiasm and to reduce stress of the employee [17].

Workplace discrimination not just damages those who are discriminated against, but it has the ability to damage the entire organization in terms of structure as well as values. Research [18] shows that discrimination in the organization has more negative impact on the employee performance and in the long run negatively affect the performance of the entire organization. However, Gender discrimination, Religion discrimination and Ethnic discrimination were negatively correlated with quality of work and employee efficiency.

\section{Statement of the Problem}

The problems in the workplace arising from discrimination are clearly evident. The way to identify and eliminate the discrimination in the work place still needs to be identified. Especially in the higher education sector, there has been great discrimination activities which appear in the form of selection, promotion, facilities etc. rather than more qualified individuals which they liken to trust and security.

The most common organizational vice in educational sector is that when work place discrimination occurs, the employees can suffer retaliation for opposing them or reporting violations to the concerned authorities. Discrimination in any form always results in inequalities and could result in poor morale of employee, stress, dissatisfaction, poor commitment and subsequently result in negative impact on the organizational performance. Further, the freedom of the employee to develop his capabilities and to choose and pursue his professional and personal aspirations becomes limited. The skills and competence cannot be developed, rewards to work are denied and a sense of humiliation, frustration and powerlessness takes over [19].

Workplace environments face discrimination from time-to-time, certain organizations may be structured in ways that rather increase this likelihood of biased treatment as well as subordination. A few studies have examined workplace discrimination among higher education employees or have considered how job strain and general stress might affect the workplace discrimination-mental health relationship. Studies on workplace discrimination have also focused primarily on gender and race-based differences or discrimination experiences of a single racial/ethnic minority group. However, with an increasingly diverse workforce, we need additional studies that document workplace discrimination among teachers of higher educations and 
how it's related to increase job stress, poor mental well-being and decreasing their level of performance at workplace and individual level. This study is an attempt to address these gaps.

\section{Research Objectives}

The present research has been undertaken to address the following research objectives:

- To explore the relationship between workplace discrimination, perceived stress, mental well-being, and job performance

- To evaluate the predictor for job performance and mental well-being.

- To determine the impact of demographic variables in assessing job performance, mental well-being, and perceived job stress.

A conceptual model has been proposed by the researcher to test the relationships empirically among the variables that appear to be relevant for this study. This model is based on the conceptual and theoretical framework of literature review presented earlier. The conceptual model proposed by the researcher will illustrate the relationship among the variables of the study (Figure 1).

\section{CONCEPTUAL MODEL}

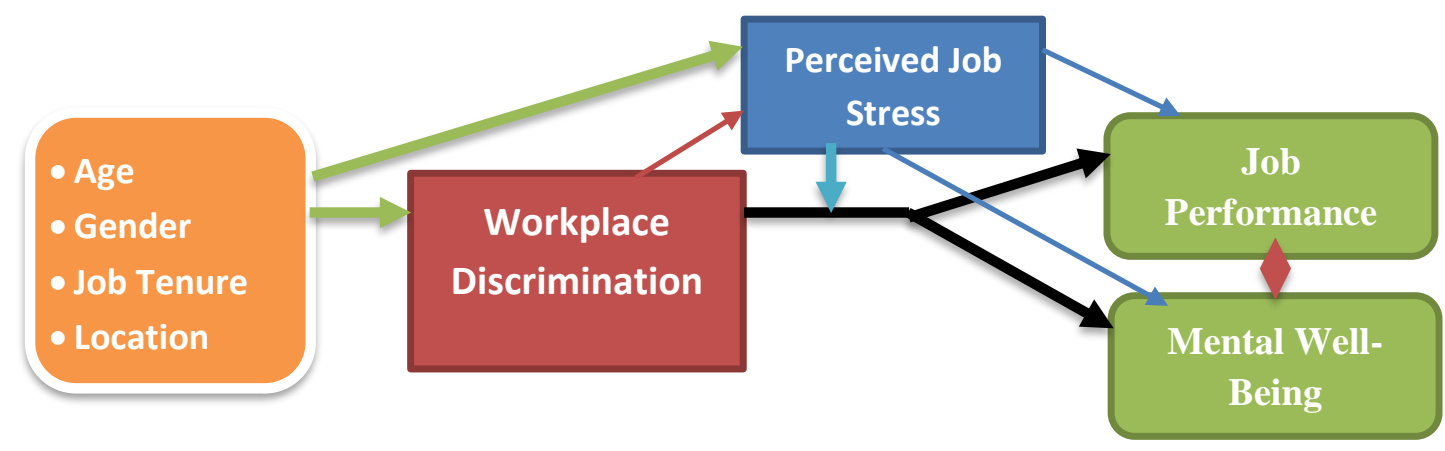

Figure 1. Illustrates the inter-relationship between different variables

\section{Hypotheses of this Study}

In order to test the relationships proposed in Model and fulfilled the objectives, the following hypotheses were formulated on the basis of the review presented and will test:

- Workplace Discrimination will negatively affect the job performance.

- Workplace Discrimination will negatively affect the mental well-being.

- Workplace Discrimination will increase the amount of perceived job stress.

- Perceived job stress will negatively affect the job performance and mental well-being.

\section{METHODOLOGY}

\section{Sample Characteristics}

Since independence we have seen a tremendous increase in the number of Universities/University in Higher Education. The sector boasts of 48 Central Universities under Ministry of Human Resource Development, India, 399 State Universities, 334 State Private universities, 126 Deemed to be Universities. The sample size of this study was 200 and convenience sampling technique was use to collect the data (Table 1).

\section{Research Design}

The study is a correlational research design, carried out to know the inter-relationship of antecedent variables (work-life balance, social-support system, time management) and outcome variable i.e., mental well-being. The study makes use of both descriptive and explanatory research methodology. The reason being that the variables taken in the research, cannot be quantified or captured by any single research method. A study of 
this nature requires administration of questionnaires to collect a wide range of opinions on the subject matter. Further, self-administered standardized questionnaire was used to gather all relevant information on subject matter. The study is descriptive in nature and uses the Normative Survey method.

\section{Description of the Research Tools}

Perceived Job Stress: It consisted of a modified version of the scale developed and standardized by Pareek [20] to measure job stress. Pareek has given a very comprehensive classification of stress at one's job. The scale has 25 items and assesses the following ten types of stressors which the employees experience on their job and operationalize in terms of inter-role distance role stagnation, role expectation conflict, role erosion, role overload, role isolation, personal inadequacy, self-role distance, role ambiguity, and resource inadequacy. A five-point rating scale was used to measure it from (1) strongly agree to (5) strongly disagree. The scale was tested for reliability (internal consistency), and Cronbach alpha was found to be .945 on 25 items. High score indicated lower level of perceived job stress and, lower levels were interpreted as high levels of perceived job stress.

Scale of Mental Well-Being: The Warwick-Edinburgh Mental Well-being Scale (WEMWBS) is a 14-item validated Hindi version measure of mental well-being that has been used nationally, regionally and locally and seen as an effective tool. It is a self-completed (aged 13+) to record 'statements about their thoughts and feelings over the past two weeks' time on a 5 Point rating scale (e.g. $1=$ Never, and $5=$ Always). The scale was tested for reliability under the Indian conditions and Cronbach alpha was found to be .776 (11 on item). High score indicated high level of mental-well-being and, lower levels were interpreted as low levels of mental well-being.

Job Performance Scale: The scale is a self-developed single item assess overall job performance of teachers in higher education. A five-point rating scale was used to measure it from (1) Very Satisfactory to (5) Very Unsatisfactory where high score indicates very unsatisfactory self-assessment of own job performance and low score was interpreted as satisfactory self-assessment of own job performance.

\section{STATISTICAL ANALYSIS}

The obtained data were analysis with the help of SPSS 25 (A Statistical Packages for Social Science Research). For this study, researcher has used univariate analysis of demographic variables, analysis of variance, bivariate correlation and stepwise regression was used to assess the predictor of mental well-being and job performance of teachers.

\section{RESULTS}

Table 1: Demographic profile of sample

\begin{tabular}{|c|c|c|}
\hline \multicolumn{2}{|c|}{ Demographic Profile } & Total N=200 \\
\hline \multirow{2}{*}{ Gender } & Male & 129 \\
\cline { 2 - 3 } & Female & 71 \\
\hline \multirow{3}{*}{ Marital Status } & Married & 123 \\
\cline { 2 - 3 } & Unmarried & 70 \\
\cline { 2 - 3 } Social Category & Divorcee & 07 \\
\cline { 2 - 3 } & General & 102 \\
\cline { 2 - 3 } & OBC & 80 \\
\hline \multirow{2}{*}{ Residence } & SC/ST & 18 \\
\hline \multirow{2}{*}{ Designation } & Urban & 141 \\
\cline { 2 - 3 } & Rural & 59 \\
\cline { 2 - 3 } & Assistant Professor & 108 \\
\cline { 2 - 3 } & Associate Professor & 62 \\
\hline Teaching Experience & Professor & 30 \\
\cline { 2 - 3 } & Up to 5 Years & 73 \\
\hline
\end{tabular}




\begin{tabular}{|l|c|c|}
\hline & More than 10 Years & 48 \\
\hline \multirow{2}{*}{ Highest Qualification } & Ph.D. & 89 \\
\cline { 2 - 3 } & Non-Ph.D./NET-JRF & 111 \\
\hline
\end{tabular}

Table 2 (a) shows the co-efficient of correlation of workplace discrimination with perceived job stress, mental well-being and overall job performance. Results from the table indicate that workplace discrimination is positively related with perceived job stress (since the direction of the scale is reverse) and it's found significant at .001 level. While, workplace discrimination is negatively related with mental well-being and overall job performance (the direction of the scale is reverse) of teachers and found significant at .001 level.

Table 2(a): Correlation between workplace discrimination and perceived job stress, mental well-being and overall job performance of teachers in higher education. $(\mathrm{N}=200)$

\begin{tabular}{|c|c|c|c|}
\hline Variable & $\begin{array}{c}\text { Perceived Job } \\
\text { Stress }\end{array}$ & $\begin{array}{c}\text { Mental Well- } \\
\text { Being }\end{array}$ & $\begin{array}{c}\text { Overall Job } \\
\text { Performance }\end{array}$ \\
\hline $\begin{array}{c}\text { Workplace } \\
\text { Discrimination }\end{array}$ & $-.504^{* *}$ & $-.378^{* *}$ & $.491^{* *}$ \\
\hline \multicolumn{3}{|c|}{${ }^{* *} . p>0.01$} &
\end{tabular}

Note: *Lower Scores on Workplace Discrimination indicates Minimum Discrimination at Workplace while Higher Scores indicates Maximum Discrimination at Workplace *Lower Scores on Job Performance indicates Higher Job Performance while Higher Scores indicates lower Job Performance *Lower Scores on Perceived Job Stress indicates Higher Perceived Job Stress while Higher Scores indicates lower Perceived Job Stress. *Lower Scores on Mental Well-Being indicates Poor Status of Mental WellBeing while Higher Scores indicates Better Mental Well-Being

Omoh, and others [21] evaluated workplace discrimination and its influence on employees' performance in Ghana. The employees in Ghana do not see workplace discrimination as strange actions by managers that will influence their performance negatively. Shahhossa and others [22] examined the effect of workplace discrimination on the job performance of the individuals from a theoretical viewpoint. More specifically, it embarks on the link between the nature of workplace discrimination and the job performance. The study discovered a positive correlation between workplace discrimination and job performance.

Table 2(b): Correlation between workplace discrimination and perceived job stress, mental well-being, overall job performance of teachers in higher education on gender basis. $(\mathrm{N}=200)$

\begin{tabular}{|c|c|c|c|c|}
\hline Variable & Gender & $\begin{array}{l}\text { Perceived Job } \\
\text { Stress }\end{array}$ & $\begin{array}{c}\text { Mental Well- } \\
\text { Being }\end{array}$ & $\begin{array}{c}\text { Overall Job } \\
\text { Performance }\end{array}$ \\
\hline \multirow{2}{*}{$\begin{array}{c}\text { Workplace } \\
\text { Discrimination }\end{array}$} & Male & -.355 & $-.247^{\mathrm{Ns}}$ & $.453^{*}$ \\
\hline & Female & $-.664^{* *}$ & $-.583^{* *}$ & $.543^{* *}$ \\
\hline
\end{tabular}

Results of Table 2 (b) shows that in case of male teachers, workplace discrimination is only found significant $(.05$ Level) negative correlation with overall job performance (direction of the scale is reverse) while a positive relationship between workplace discrimination with perceived job stress and negative relationship found with mental well-being but the relationships are not found significant. In case of female teachers, workplace discrimination is positively related with perceived job stress (since the direction of the scale is reverse) and it's found significant at .001 level. While, workplace discrimination is negatively related with mental well-being and overall job performance (the direction of the scale is reverse) of female teachers and found significant at .001 level. In the workplace, women are commonly exposed to understated discrimination by both the genders.

The qualified women may be passed over for promotions due to reasons like, pregnancy. Jobs may be offered to a less qualified male applicant just because he is a male candidate. Negative stereotypes in the organization affect the perception of most employees in the organization. It is evident that most stakeholders hold that 
women are weak and thus cannot qualify for leadership positions and in jobs that require physical strength. The gender stereotype has affected the participations of women in the organization. Besides, the negative stereotypes have to discrimination in remunerations in the organization [23]. Women receive a small figure of salaries than the male counterpart in the same job descriptions. As a result, most women are less motivated and show a relatively lower motivation in the workplace. The quality of work in the sections held by women is low because of the belief of their inabilities.

Table 2(c): Correlation between workplace discrimination and perceived job stress, mental well-being, overall job performance of teachers in higher education on location of their institute/college/university basis. $(\mathrm{N}=200)$

\begin{tabular}{|c|c|c|c|c|}
\hline Variable & Location & $\begin{array}{c}\text { Perceived } \\
\text { Job Stress }\end{array}$ & $\begin{array}{c}\text { Mental } \\
\text { Well-Being }\end{array}$ & $\begin{array}{c}\text { Overall } \\
\text { Job Performance }\end{array}$ \\
\hline Workplace & Rural Area & -.336 & -.167 & .327 \\
\cline { 2 - 5 } Discrimination & City Area & $-.559^{* *}$ & $-.494^{* *}$ & $.557^{* *}$ \\
\cline { 2 - 4 } & \multicolumn{2}{|c|}{$p>.01 ;{ }^{* *} \cdot p>.05, \&^{\text {Ns }}$ Not found Significant at any level of significance (2-tailed). }
\end{tabular}

*Lower Scores on Workplace Discrimination indicates Minimum Discrimination at Workplace while Higher Scores indicates Maximum Discrimination at Workplace

*Lower Scores on Job Performance indicates Higher Job Performance while Higher Scores indicates lower Job Performance

*Lower Scores on Perceived Job Stress indicates Higher Perceived Job Stress while Higher Scores indicates lower Perceived Job Stress

Lower Scores on Mental Well-Being indicates Poor Status of Mental Well-Being while Higher Scores indicates Better Mental Well-Being

Results of Table 2 (c) shows that in the case of teachers belonging to the rural area, workplace discrimination is not found a significant correlation with overall job performance, perceived job stress, and mental wellbeing, but the directions of the relationships indicate a negative relationship among them. In the case of teachers belongs to the city area, workplace discrimination is positively related to perceived job stress (since the direction of the scale is reverse), and it's found significant at .001 level. While, workplace discrimination is negatively related to mental well-being and overall job performance (the direction of the scale is reverse) of female teachers and found significant at .001 level.

Table 2 (d). Correlation between different aspects of discrimination at workplace and overall job performance, perceived job stress, mental well-being of teachers in higher education on gender basis.

$(\mathrm{N}=\mathbf{2 0 0})$

\begin{tabular}{|l|c|c|c|}
\hline \multicolumn{1}{|c|}{$\begin{array}{c}\text { Different Aspects of } \\
\text { Discrimination at Workplace }\end{array}$} & $\begin{array}{c}\text { Overall Job } \\
\text { Performance }\end{array}$ & $\begin{array}{c}\text { Perceived } \\
\text { Job Stress }\end{array}$ & $\begin{array}{c}\text { Mental } \\
\text { Well- } \\
\text { Being }\end{array}$ \\
\hline 1. Based on Age & $.524^{* *}$ & $-.496^{* *}$ & $-.506^{* *}$ \\
\hline 2. Based on Sex & $.362^{* *}$ & $-.461^{* *}$ & $-.389^{* *}$ \\
\hline 3. Based on Religion & $.439^{* *}$ & $-.352^{*}$ & $-.331^{*}$ \\
\hline 4. Based on Community & $.469^{* *}$ & $-.447^{* *}$ & -.272 \\
\hline 5. Favouritism & $.314^{*}$ & $-.308^{*}$ & $-.281^{*}$ \\
\hline 6. Disability or invalidity & .206 & $-.393^{* *}$ & $-.388^{* *}$ \\
\hline 7. At the time of hiring or appointment? & .100 & $-.358^{* *}$ & -.055 \\
\hline 8. In Remuneration & $.565^{* *}$ & $-.348^{*}$ & -.265 \\
\hline 9. In gaining appreciation & $.290^{*}$ & $-.365^{* *}$ & $-.327^{*}$ \\
\hline 10. In career advancement opportunities & $.326^{*}$ & $-.398^{* *}$ & -.130 \\
\hline 11. In distribution of work or shifts & $.511^{* *}$ & $-.440^{* *}$ & $-.358^{* *}$ \\
\hline 12. In access to training arranged by the employer & .206 & -.168 & -.096 \\
\hline 13. In receiving information & .258 & $-.282^{*}$ & -.257 \\
\hline 14. In gaining employment fringe benefits & $.451^{* *}$ & $-.373^{* *}$ & -.223 \\
\hline
\end{tabular}


15. In the attitudes of co-workers or superiors

$.362^{* \star}$

$.392^{* *}$
$-.352^{\star}$

**. Correlation is significant at the 0.01 level (2-tailed).

*. Correlation is significant at the 0.05 level (2-tailed).

\section{Predictors of Overall Job Performance and Mental Well-Being}

Table 3(a): Regression analysis for job performance of teachers with different demographic variables, workplace discrimination and perceived job stress.

\begin{tabular}{|c|c|c|c|c|c|c|c|c|}
\hline Predictors & $\begin{array}{c}\text { Dependent } \\
\text { Variable }\end{array}$ & $\mathbf{R}$ & $\mathbf{R}^{2}$ & $\begin{array}{c}\mathbf{R}^{2} \\
\text { Chan } \\
\text { ge }\end{array}$ & $\mathbf{F}$ & $\boldsymbol{\beta}$ & $\begin{array}{c}\mathrm{t}- \\
\text { value }\end{array}$ & Sig. \\
\hline Perceived Job Stress & \multirow{3}{*}{$\begin{array}{c}\text { Job } \\
\text { Performance }\end{array}$} & $.648^{\mathrm{a}}$ & .420 & .420 & $35.432 * * *$ & -.462 & -3.860 & .000 \\
\hline Job Tenure & & $.692^{\mathrm{b}}$ & .479 & .059 & $22.064^{* * *}$ & -.271 & -2.620 & .012 \\
\hline Workplace Discrimination & & $.725^{\mathrm{c}}$ & .525 & .046 & $17.334^{* * *}$ & .250 & 2.140 & .038 \\
\hline \multicolumn{9}{|c|}{ a. Predictors: (Constant), Perceived Job Stress } \\
\hline \multicolumn{9}{|c|}{ b. Predictors: (Constant), Perceived Job Stress, Job Tenure } \\
\hline
\end{tabular}

Table 3(a) indicates that perceived job stress, job tenure, and workplace discrimination explain significant contribution (best predictors of job performance) and $42.0 \%$ variance in predicting job performance by perceived job stress $(\mathrm{F}=35.432, \mathrm{p}>.000$, $\mathrm{t}$-value $=-3.860, \mathrm{p}>.000), 5.9 \%$ variance by job tenure $(\mathrm{F}=22.064, \mathrm{p}>.000, \mathrm{t}$-value $=-2.620, \mathrm{p}>.012)$, and $4.6 \%$ variance by workplace discrimination $(\mathrm{F}=17.334, \mathrm{p}>.000, \mathrm{t}-\mathrm{value}=-2.140, \mathrm{p}>.038)$. The obtained results clearly revealed that perceived job stress and workplace discrimination are negatively related to job performance and job tenure is positively related job performance. This shows that with decreases in amount of job stress and discrimination at workplace, performance of teachers increases and as the experience (job tenure) increases, job performance improves. On the other hand, other antecedent variables are not significantly contributing the job performance of teachers.

Table 3(b): Regression analysis for mental well-being of teachers with demographic variables, workplace discrimination and perceived job stress.

\begin{tabular}{|l|c|c|c|c|c|c|c|c|}
\hline Predictors & $\begin{array}{c}\text { Dependent } \\
\text { Variable }\end{array}$ & $\mathbf{R}$ & $\mathbf{R}^{2}$ & $\begin{array}{c}\mathbf{R}^{2} \\
\mathbf{C h a n} \\
\text { ge }\end{array}$ & $\mathbf{F}$ & $\boldsymbol{\beta}$ & $\begin{array}{c}\text { t- } \\
\text { value }\end{array}$ & Sig. \\
\cline { 1 - 9 } Perceived Job Stress & $\begin{array}{c}\text { Mental } \\
\text { Well-Being }\end{array}$ & $.735^{\mathrm{a}}$ & .540 & .540 & $57.548^{* * *}$ & .767 & 8.409 & .000 \\
\cline { 1 - 8 } & & $.779^{\mathrm{b}}$ & .607 & .067 & $37.009^{* * *}$ & -.260 & -2.849 & .006 \\
\hline Gender & & \\
\hline
\end{tabular}

Table 3(b) indicates that perceived job stress and gender explain significant contribution (best predictors of mental well-being) and $54.0 \%$ variance in predicting mental well-being of teachers by perceived job stress $(F=57.548, p>.000, t$-value $=8.409, p>.000)$ and $6.7 \%$ variance by gender $(F=37.009, p>.000, t-$ value $=-2.849, p>.006$ ). The obtained results clearly revealed that perceived job stress is negatively related to mental well-being and gender play a role in own's evaluation of job performance. This shows that with decreases in amount of job stress and will increase the mental well-being of teachers. On the other hand, other antecedent variables are not significantly contributing the mental well-being of teachers.

The main limitations of the study are related to time, sample size, and hesitation among the teachers in their views. Moreover, around 50 percent of the sample belongs to assistant professor level. The other limitations of the study are:

1. The data is based on purely one's individual opinion which may bring in some biasness and varies in terms of their position, experience, regional institutional culture and support. 
2. The survey has been conducted on a small sample of 200 teachers teaching in colleges and Universities of Uttar Pradesh, Jharkhand, Tamil Nadu, Maharashtra and their representation is also not very much comparable (most of the teachers belong to Uttar Pradesh), even they can vary in terms of college and university's teachers. Therefore, the findings of the study are not generalizable and applicable to teachers of different states.

3. Further, study can be planned in keeping these issues that will give us a more generalized view regarding the issues taken in this study.

Table 3(c): Regression analysis for perceived job stress of teachers with demographic variables, workplace discrimination and perceived job stress.

\begin{tabular}{|c|c|c|c|c|c|c|c|c|c|}
\hline Predictors & $\begin{array}{l}\text { Dependent } \\
\text { Variable }\end{array}$ & $\mathbf{R}$ & $\mathbf{R}^{2}$ & $\begin{array}{c}\mathbf{R}^{2} \\
\text { Cha } \\
\text { nge }\end{array}$ & $\mathbf{F}$ & $\boldsymbol{\beta}$ & $\begin{array}{c}\mathrm{t}- \\
\text { value }\end{array}$ & Sig. & $\begin{array}{c}\text { Durbi } \\
\text { n- } \\
\text { Wats } \\
\text { on }\end{array}$ \\
\hline Mental Well-Being & \multirow{3}{*}{$\begin{array}{l}\text { Perceived } \\
\text { Job Stress }\end{array}$} & $.735^{\mathrm{a}}$ & .540 & .540 & $57.548^{* * *}$ & .687 & 7.090 & .000 & \\
\hline Gender & & $.776^{\mathrm{b}}$ & .602 & .062 & $36.279 * * *$ & .211 & 2.340 & .024 & \\
\hline $\begin{array}{l}\text { Workplace } \\
\text { Discrimination }\end{array}$ & & $.801^{\mathrm{c}}$ & .641 & .040 & $28.033^{* * *}$ & -.219 & -2.280 & .027 & 1.898 \\
\hline \multicolumn{10}{|c|}{ a. Predictors: (Constant), Mental Well-Being } \\
\hline b Predictors: (Co & $\pi$ & 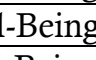 & Iue & & & & & & \\
\hline
\end{tabular}

\section{CONCLUSIONS}

Although, this study gives a clear picture of workplace discrimination, job stress, mental well-being and job performance of teachers. It shows following results that may be further testify with large data:

- Workplace discrimination perceived by teachers is shown in terms of increase level of job stress that further deteriorates the mental well-being and overall job performance of teachers in higher education.

- In case of male teachers, workplace discrimination is only found significant negative correlation with overall job performance and a positive relationship between workplace discrimination with perceived job stress and negative relationship found with mental well-being but the relationships are not found significant. On the other hand, in case of female teachers, workplace discrimination is significantly positively related with perceived job stress and negatively related with mental well-being and overall job performance.

- Discrimination based on age, sex, religion, community, favouritism, allocation of remunerations, gaining appreciation, career advancement opportunities, distribution of work, gaining employment fringe and attitude of co-worker or supervisors are found negatively correlated with job performance.

- Discrimination based on age, sex, religion, community, disability or invalidity, at the time of joining/hiring, favouritism, allocation of remunerations, gaining appreciation, career advancement opportunities, distribution of work, gaining employment fringe, receiving information and attitude of co-worker or supervisors are found negatively correlated with mental well-being.

- Discrimination based on age, sex, religion, disability or invalidity, favouritism, gaining appreciation, distribution of work, and attitude of co-worker or supervisors are only found significantly negatively correlated with mental well-being while shows negative correlation with others aspects of discrimination, but not found significant.

- Results shows that there is a significant difference found between teachers having less and more job tenure in their assessments of job performance that indicate that teachers having more job tenure have better assessment of their job performance than teachers having less job tenure.

- Further, stepwise regression analysis shows that perceived job stress, job tenure, and workplace discrimination explain significant contribution (job stress emerged as best predictors of job 
performance) to job performance of teachers while in case of best predictor of mental well-being perceived job stress and gender explain significant contribution (job stress again emerged as best predictors of mental well-being) to mental well-being of teachers.

\section{REFERENCES}

1. EEOC EG. Unlawful disparate treatment of workers with care giving responsibilities; 2009.

$\begin{array}{lllll}\text { 2. Equal } & \text { Opportunity } & \text { Act } & 2010 & \text { downloaded }\end{array}$ http://www.legislation.vic.gov.au/domino/Web_Notes/LDMS/LTObject_Store/LTObjSt6.nsf/DDE300B 846EED9C7CA257616000A3571/6A457BE6293E797DCA25796D0014F920/\$FILE/1016aa011\%20author ised.pdf

3. Ruggiero KM, Taylor DM. Why minority group members perceive or do not perceive the discrimination that confronts them: The role of self-esteem and perceived control. J Personal Soc Psychol 1997;72(2):373-80.

4. Hirsh CE, Kornrich S. The context of discrimination: Workplace conditions, institutional environments, and sex and race discrimination charges. Am J Sociology 2008;113(5):1394-1432.

5. Pavalko EK, Mossakowski KN, Hamilton VJ. Does perceived discrimination affect health? longitudinal relationships between work discrimination and women's physical and emotional health. J Health Soc Behav 2003;44(1):18-33.

6. Roberts RK, Swanson NG, Murphy LR. Discrimination and occupational mental health. J Ment Health 2004;13(2):129-42.

7. Wadsworth E, Dhillon K, Shaw C, Bhui K, Stansfeld S, Smith A. Racial discrimination, ethnicity and work stress. Occup Med 2007;57(1):18-24.

8. Equal Opportunity Act 2010 downloaded from http://www.legislation.vic.gov.au/domino/Web_Notes/LDMS/LTObject_Store/LTObjSt6.nsf/DDE300B 846EED9C7CA257616000A3571/6A457BE6293E797DCA25796D0014F920/\$FILE/1016aa011\%20author ised.pdf

9. Indian Express. https://indianexpress.com/article/gender/the-workplace-is-still-a-venue-fordiscriminationshows-report-5079670/

10. The HERI Faculty Survey 2016-2017) Download from https://heri.ucla.edu/monographs/HERIFAC2017monograph.pdf

11. Contrada RJ, Ashmore RD, Gary ML, Coups E, Egeth JD, Sewell A, et al. Measures of ethnicity-related stress: Psychometric properties, ethnic group differences, and associations with well-being. J Appl Soc Psychol 2011;31:1775-1820.

12. Clark R, Anderson NB, Clark VR, Williams DR. Racism as a stressor for African Americans: A biopsychosocial model. Amer Psychol 1999;54: 805-16.

13. Hughes D, Dodge MA. African American women in the workplace: Relationships between job conditions, racial bias at work, and perceived job quality. Am J Commun Psychol 2001;25(5):581-99.

14. Landrine H, Klonoff EA. The Schedule of Racist Events. J Black Psychol 1996;22:144-68.

15. Hunter CD, Lewis-Coles ME. Coping with racism: A spirit-based psychological perspective. The Psychol Prejud Discrimination 2004;1:207-22.

16. Bowling NA, Beehr TA. Workplace harassment from the victim's perspective: A theoretical model and metaanalysis. J Appl Psychol 2006;91:998-1012.

17. Hershcovis MS, Barling J. Towards a multi-foci approach to workplace aggression: A meta-analytic review of outcomes from different perpetrators. J Organiz Behav 2011;31(1):24-44.

18. Lazarus RS, De Longis A, Folkman S, Gruen R. Stress and adaptational outcomes: The problem of confounded measures. Amer Psychol 1985;40:770-9.

19. Channar ZA, Abbassi Z, Ujan IA. Gender discrimination in workforce and its impact on the employees. Pak J Comm Soc Sci 2012;5(1):177-91.

20. Isaiah OD, Ojiabo U, Alagah AD. Workplace discrimination and employee performance in Nigerian food and beverage sector. Int J Adv Acad Res Soc Manage Sci 2015;3(11):61-85.

21. Olsen DS, Tikkanen T. The developing field of workplace learning and the contribution of PIAAC. Int J Lifelong Educ 2018;37(5):546-59.

22. Pareek U. Role stress scales (Research Report). Ahmedabad: Indian Institute of Management; 1981.

23. Omoh GD, Owusu EE, Mendah AF. Workplace discrimination and its influence on employee performance: The case of Ghana. Int J Inform Business Manag 2015;7(3):2260231.

24. Shahhossa M, Silong AD, Ismail IA, Uli JN. The role of workplace discrimination on job performance. Int J Business Soc Sci 2012;3(21). 
25. Posthuma RA, Wagstaff MF, Campion MA. 16 Age Stereotypes and Workplace Age Discrimination. The Oxford Handbook of Work and Aging 2012;298.

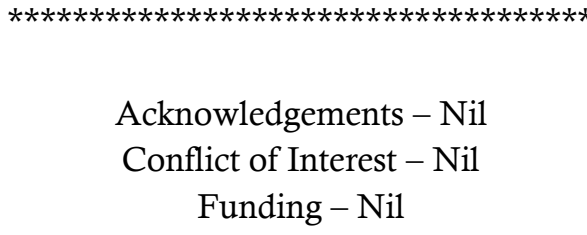

